\title{
The Main Barriers to Export from The Free Trade Zones (Case Study of I.R.IRAN)
}

\author{
Seyed Morteza Safavi ${ }^{1}$ \\ ${ }^{1}$ Armenian National Agrarian University, Yerevan, Armenia \\ Correspondence: Seyed Morteza Safavi, Business Department, Armenian National Agrarian University, Yerevan, \\ Armenia. E-mail: Dr.safavi@hotmail.com
}

Received: June 15, 2015 Accepted: July 16, 2015 Online Published: August 18, 2015

doi:10.5539/ass.v1 $1 \mathrm{n} 24 \mathrm{p} 277$

URL: http://dx.doi.org/10.5539/ass.v11n24p277

\begin{abstract}
Currently, future industrial development is contingent upon free zones, where the export of industrial goods, expansion of international trade, generation of new job opportunities and subsequent decrease in unemployment occurred. Free economic zones of the Islamic Republic of Iran were also established with the aim of cultural, economic and social plans to connect to international markets. The aim of this article is to focus on the main barriers that exist to export from the free trade zones in the country. In order to understand how Iranian exporters surmount obstacles and other variables including barriers related to human resources, financial issues and the market in free trade zones, we investigated the existing relationship and variables involved in export boost. The results obtained indicated that in developing markets, firms lack the essential managerial obligations to export and meet demands of the foreign market. Thus, major significant managerial capabilities and competencies are required for recognition of export barriers by adopting the best possible strategies.
\end{abstract}

Keywords: Anzali free trade zone, export barriers, free trade zones, financial barrier, human resources barriers

\section{Introduction}

During the first five-years, Iran's economic plan had been put into operation in 1989 to accomplish immediate reconstruction and economic recovery objectives following the imposed Iraqi war. The plan intended to exponentially extend the managed economy of the war to have a broader international scope based on consistent presence and long-standing global relationships. Since there have been some limitations, the plan faced problems in the market. On the other hand, changes in the local economy were inevitable. The state decided to select some locations as free economic zones to expedite processing and tackle export problems.

The act of free zone was passed by the Iranian parliament on September 1993, based on which Kish and Qeshm Islands as well as Chabahar port were named as free zones of the country and 4 subsequent locations, namely Aras, Arvand, Anzali, and Makoo were later added to these zones. Besides these, 23 special economic zones currently exist in Iran and are growing increasingly in number because of their positive impact on the economy, industry, and production. Consequently, the council of ministers created the free zones' bylaw, through which all regulations concerning investment, labour, import, export, banking, and employment of these zones were considered.

Free trade and special economic zone are territories controlled by the Iranian government. According to a certain local law and bylaws, these locations are free from any customs regulations for import and export. Since these zones are located in a special area, they enjoy ample developed infrastructure and are charged with foreign investment incentives. They provide a special opportunity for local and foreign investment.

The goal of this study is to extend Iran's economy by concentrating on enhancing the export issues in free trade zones. In order to achieve the objective of this study, the following goal should be fulfilled:

To determine the extent to which the Iranian exporters are aware of export barriers in free trade zones and the relationship between awareness and other factors included. Moreover, export performance is investigated using the provided variables and are far from the study objectives. The scope of this research is determined by the research question and provides the overall direction. 


\subsection{The Research Question Is as Follows}

What are the major barriers in free trade zones? How are they perceived by the Iranian exporters? And to what extent has this awareness affected the export performance?

\subsection{Study Area}

The study is conducted in the realm of export companies in the free trade zone of Anzali port, a major location which is located to the north of Iran besides the Caspian Sea. If the focus of study was in the private sector and individual entrepreneurs, more appropriate results could be obtained as they do not work with any governmental support and understand the barriers better. However, the main focus is on the obstacles and problems faced by the companies in the Anzali free trade zone.

\section{Literature Review}

\subsection{Free Trade and Special Economic Zones in Iran}

Free trade and special economic zones are areas which are involved within the realm of the Iranian government. They have their own specific regulations and more importantly they are exempted from customs services and all goods and commodities can enter the country freely within certain stipulated regulations. These areas provide the major elements of investment, including specific geographical zones, required infrastructures as well as foreign investment incentives all of which make local and international investment possible (Hakimian, 2011).

Free trade zones in Iran have the following legal advantages:

1. Foreign investment support and guarantee.

2. The possibility of exporting a part of manufactured products to the motherland with no customs duties.

3. The possibility of foreign investment in any amount, namely to the total proportion of the investment.

4. Full freedom of entry and exit of capital and its resultant interest.

5. Granting visa and issuing the required certificate for residency of the foreigners.

6. Providing facilitated laws and regulation for working relationships, employments, and social security.

7. Free import of products to and from the zone with no customs duties.

8. Tax exemption for 20 years from the operation date for all economic activities.

9. Use of trained and expert human resources in all occupational levels.

10. Use of raw oil and gas materials as raw materials and fuel in all industrial activities.

\subsection{Free Trade Zone of Anzali}

The Anzali free trade zone is located in Gilan province, north of Iran. According to the latest political divisions, the area allocates to itself parts of Anzali and Rasht cities and encompasses 14 rural districts. Some parts of the Ligaraki Hassan Rood village from the central district of the Anzali City, Haji Bakandeh village from the Khoshbijar district of the Rasht City, and Khamam village of Khamam district of the Rasht City were included in the free zone. The Anzli free zone comprises of 3200 hectares of land area and $40 \mathrm{~km} / \mathrm{m} 2$ of marine area (Miandehi \& Masrouri, 2013). The zone also covers the Golshan area (the commercial and industrial section of the district), Hassan Rood industrial town and the port area of Department of Ports and Maritime of Gilan province. The issue enhanced the attraction and desirability of free commercial-industrial zone of Anzali and increased the chances for legal authorities to present facilities regarding loading and unloading and other related procedures.

\subsubsection{Geographical Location}

Sharing a common border with Gilan province, the port of Anzali is located 23 kilometers east of the town, with the Caspian Sea on the north and Fatato village and Ghazian in the north. Anzali Bay is also located to the west of the town and the Khomam highway from the West to the North West. The area comprises of two different sections in the west and the north, each of which has its specific functionality.

\subsubsection{Economic and Geographical Advantages}

There are some port installations, facilities, and maritime transportations in the north-south international corridor of Nostrac, also known as the transit corridor of Asia-Europe of the $21^{\text {st }}$ century and considered to be the most salient feature of the Anzali port. The corridor connects the Helsinki port (North Europe) via Russia to the north $\&$ southern ports of the Caspian Sea, and passes through the Persian Gulf to the south-eastern countries of Asia. 
Some of other characteristics that distinguish the Anzali port are as follows:

1. It is the nearest free zone to the capital (Tehran) and other industrial and densely populated centers of the country, namely referred to as consumption markets.

2. Special location with concern to the relationship with the Caspian Sea Countries.

3. Proximity within Astarakhan and Lagan ports in Russia, Krasnovodsk in Turkmenistan, Aktau in Kazakhstan, and Bako in Azerbaijan.

4. Access through appropriate roads to market countries in CIS.

5. Proximity to Rasht International Airport facilitated with full navigation instrument.

6. Totally delineated zone with complete Geographical Information System.

7. Proximity within the largest oil and gas reservoirs of the Caspian Sea.

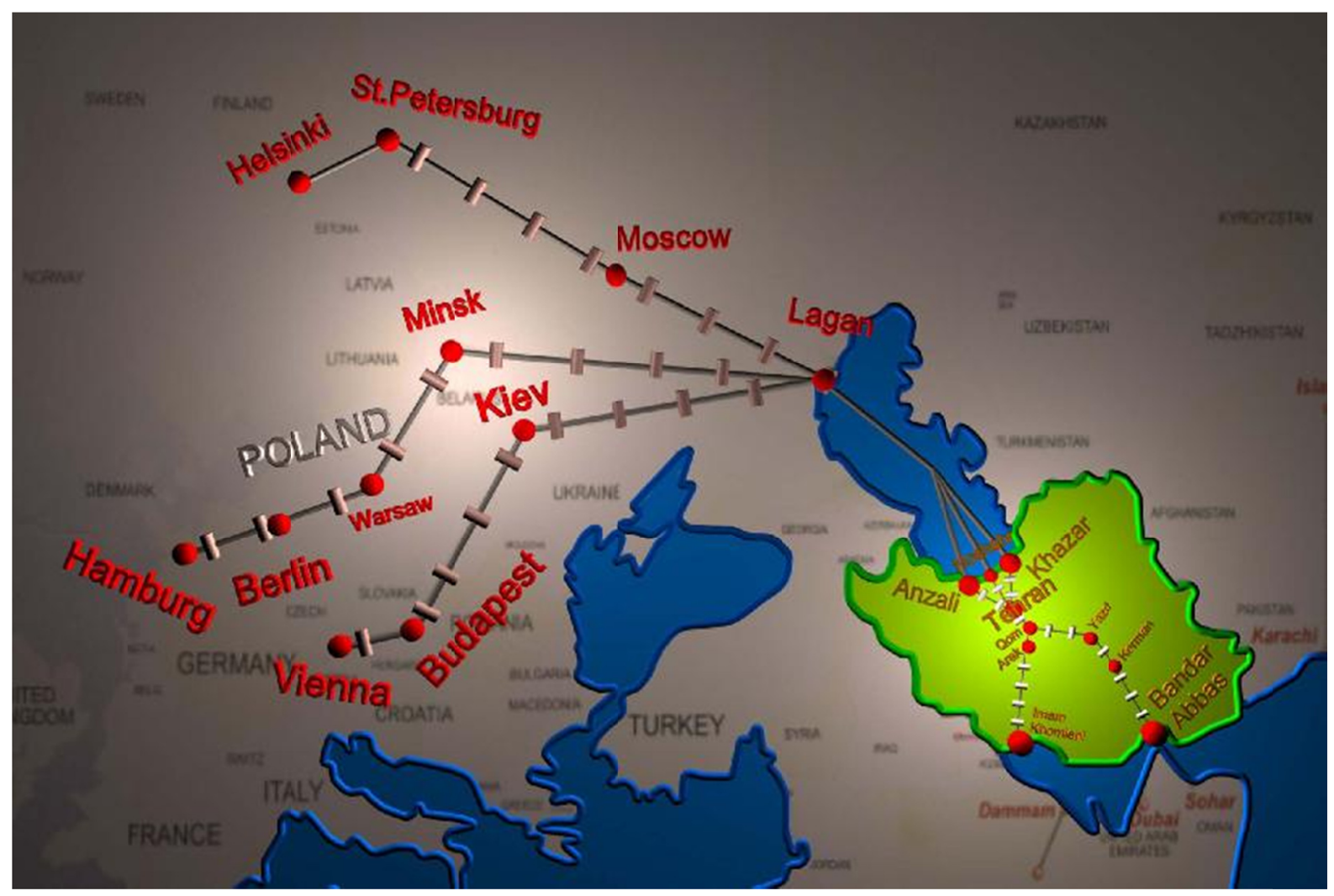

Figure1. Location of Anzali Port

\subsubsection{Special Legal Incentives to Support the Free Trade Zone of Anzali}

According to the stipulated law of the council of ministers, those practitioners working within the framework of the free trade zone, including Anzali port can enjoy the following privileges:

- Natural and legal persons who perform different economic activities in the zone are exempted from taxation of income and assets mentioned in the direct taxation act for fifteen years which is increased to twenty years from now on from the exploitation date set forth in the license

- Commercial foreign exchanges of the zones are excluded from import and export regulations after customs registration. The terms of export and import of goods and customs formalities will be passed within the realm of each region by the council of ministers

- Import of manufactured products to the free zone and to the rest of country is exempted from full or partial customs duties. The commercial interest is up to the level of value added tax in that region 
- Import of products of which all or part of its raw materials were supplied in the country and manufactured in the free zone is exempted from full or atrial customs duties and commercial interest in relation to local raw materials.

- Entry and exit of capital and the resultant profit of economic activities is free in any zone.

- Legal capital and rights of foreign investors whose capital was approved by the council of ministers are under full support and guarantee of Foreign Investment Protection Act of Organization for Investment, Economic and Technical Assistance of Iran

- Import of machinery, raw materials and equipment to free industrial-commercial zones of Anzali is exempted from custom duties and commercial interest.

- Exemption from cargo transit duties from free zones to the output borders

- A visa is not required for foreign nationals

- Easy registration process for companies, industrial institutions, cultural institutions and intellectual property in relation to regulations specific to the free zones

- Facilitated land sell or lease for Iranians and providing long term lease for foreign nationals

- Pursuing specific regulations for monetary and banking operations to have flexible monetary and banking services

Table 1. Anzali port facilities and equipment

\begin{tabular}{lccc}
\hline No & Description & Unit & Capacity (power) \\
\hline 1 & Shore crane & 2 & 100 tons \\
2 & Shore crane & 1 & 120 tons \\
3 & Mobile crane & 1 & 60 tons \\
4 & Shore Cranes & 3 & 60 tons \\
5 & Loading /unloading cranes & 5 & $36-54$ tons \\
6 & Reach stacker & 2 & 45 tons \\
7 & Transtainer & 1 & 42 tons \\
8 & Tug boat & 3 & 1500 Hp \\
9 & Pilot & 2 & - \\
\hline
\end{tabular}

\section{Method}

\subsection{Methodological Procedures}

In this article, different effective factors including sampling plan and characteristics, data collection and various variable measurements have been explained. Data was collected involving the export problems perceived by the managers in related activities and export performance of these firms. The aim of this paper is to provide data on the export part of the Iranian export industry in Anzali free trade zones. Descriptive research design is used in the conduct of this research. This was done as a result of the above reasons. Research questions were well-organized and the focus is mainly on the cause and effect phenomena to reach the desired answers. A well-defined research question and accurate rules and procedures in the choice of a particular technique are what was explained in the research design. Both the SPSS 20.0 and LISREL 8.80 (Linear Structural Relations) statistical programs have been used for data analysis.

Participants attended from different industries and firm sizes. Firms were selected from micro, small and medium scales. The size distribution of firms that participated in the project were in direct relation with the features of export sectors in most countries which include small and medium size firms.

\subsection{Data Instrument Development}

Like other studies, the export area was considered as the unit of analysis. According to Katsikeas et al. the researcher is in charge and ensures that the unit of analysis is well understood by the participant (Katsikeas, Leonidou, \& Morgan, 2000). Similarly, to ensure consistency, the process progressed based on relevant literature 
and consultation with the project supervisor before the design of the survey data collection instrument. However, it is declared in the studies of Diamantopoulos et al. that managerial, organizational and environmental factors are important attributes that affect venture and firm level analysis as well and are of utmost significance in the development of data collecting instruments (Diamantopoulos \& Kakkos, 2007).

\subsection{Sampling Procedures and Sample Size}

A list of the 320 export firms were considered for sampling frame from which it was drawn. A number of 100 exporters were selected and needed to answer the prepared questionnaires using random sampling. All of the contacted firms were located in the free trade zone of the Anzali port. It is, however, worth mentioning that location was not considered in the selection of these firms, though some production sites of the firms were located outside the free trade zone. Due to the nature of the study, we do not consider small sample sizes a limitation to the analysis and conclusion. The most significant factor was the issue raised and the direction the results gave for further research on the export sector's development process.

Participants were identified as corporate heads, managing directors or CEO's of the various firms. Out of 100 selected participant firms, 16 were no longer involved in export activities, 5 refused to participate due to the lack of time and the location of two of the firms could not be traced.

Questionnaires were completed by participants to elicit the relationship between the firms and their major export market. Given that, closed-ended questionnaires were emailed to the participants. Out of the whole administered questionnaires six were incomplete or had been completed by ineligible participants and a response rate of $71 \%$ was achieved. The obtained rate was adequate for the study as the prior rate of the same study on the export managers by Shoham was $40.1 \%$ (Shoham \& Kropp, 1998).

\section{Data Analysis and Results}

\subsection{Target Markets}

The gathered responses indicated that their major export markets included the neighborhood countries, including Russia, Armenia, Turkmenistan, Azerbaijan, Kazakhstan, Turkey, Syria, Iraq and countries in the European Union (Ukraine, UK, France, Netherlands, Italy, Spain etc.), Asia (China, India, Japan) and the Persian Gulf. The average firm employing rate was four and the average turnover was eighty thousand US dollars.

\subsection{Perceived Export Barriers}

Using SPSS version 20.0, Principal Component Analysis was applied to twenty indicators of perceived export barriers. As depicted, variables loaded adequately on three factors in the presence of many factors with coefficients greater than 0.3 and loadings with less than 0.3 were excluded from the analysis. The Keiser measure of Sampling Adequacy was 0.691 well within the required range of 0.00 to 1.00 and exceeded the recommended value of 0.60 (Kaiser \& Rice, 1974). Moreover, Bartlett's Test of Sphericity reached statistical significance and supported the factorability of the correlation matrix (Mumford, Ayub, \& Bavington, 2005). Employing Varimax Rotation with Kaiser Normalization confirmed the relevance of the extracted factors with large factor loadings. The solution revealed the presence of a simple structure consisting of three factors. These factors were internal company barriers (comprising of two components of human resource barriers and financial barriers) and market barriers. These three factors explained $61.2 \%$ of the variance and made up about $37.3 \%$, $13.7 \%$ and $10.2 \%$ of the variance respectively. Variables which did not load sufficiently on any factor were omitted. Other variables were also discarded as they did not contribute to the explanation of any related factors. To explain the nature of factor loading which provides a basis for our classification, the content analysis of the individual described further concerning theoretical evidence was presented in our research review.

As shown in Table 2, results of our factor analysis are as follows: the left hand column, namely human resource barrier, financial barrier and market barriers show the extracted factors. Both human resource and financial barriers are types of company barriers falling under internal barriers, while market barrier is a type of external barrier. Column two illustrates the variables under consideration and columns three, four and five indicate the factor loadings respectively. 
Table 2. Component matrix of perceived export barriers

\begin{tabular}{|c|c|c|c|c|}
\hline & & 1 & 2 & 3 \\
\hline \multirow{4}{*}{$\begin{array}{l}\text { Human Resources } \\
\text { Barriers }\end{array}$} & Deficiency of foreign trade staff & \multicolumn{3}{|l|}{0.795} \\
\hline & $\begin{array}{l}\text { Issues in hiring experienced staff to accomplish } \\
\text { particular responsibilities }\end{array}$ & \multicolumn{3}{|l|}{0.794} \\
\hline & Deficiency of manager time period & \multicolumn{3}{|l|}{0.691} \\
\hline & $\begin{array}{l}\text { Deficiency of company's responsibility regards to } \\
\text { foreign trade }\end{array}$ & 0.678 & \multicolumn{2}{|l|}{0.387} \\
\hline \multirow{3}{*}{ Financial Barrier } & Delay in receiving foreign payments & \multirow{3}{*}{0.472} & \multicolumn{2}{|l|}{0.868} \\
\hline & Deficiency of fiscal support & & \multicolumn{2}{|l|}{0.856} \\
\hline & \multicolumn{3}{|l|}{$\begin{array}{l}\text { Deficiency of government familiarity with foreign trade } \\
\text { support plans }\end{array}$} & \\
\hline \multirow{3}{*}{ Market Barriers } & \multicolumn{3}{|l|}{ Bureaucratic requirements } & 0.726 \\
\hline & \multicolumn{3}{|l|}{ Quality requirements of the foreign countries } & 0.661 \\
\hline & \multicolumn{4}{|l|}{ Non-tariff barriers in export market } \\
\hline \multicolumn{2}{|l|}{ Total Variance Explained } & $33.9 \%$ & $14.9 \%$ & $10.9 \%$ \\
\hline \multicolumn{2}{|l|}{ Chronbachs Alpha } & 0.768 & 0.767 & 0.408 \\
\hline \multicolumn{2}{|l|}{ Eigenvalues } & 3.478 & 1.517 & 1.122 \\
\hline
\end{tabular}

\subsubsection{Human Resources Barrier}

The first dimension account for $33.9 \%$ of the total variation (Cronbach's $\alpha=0.768$ ). It comprises of four variables. These variables, as depicted by high positive loading consist of " Deficiency of foreign trade staff (0.795)", "Issues in hiring experienced staff to accomplish particular responsibilities (0.794)", "Deficiency of manager time period (0.691)" and "Deficiency of the company's responsibility with regards to foreign trade $(0.678)$ ". These variables are under the influence of qualified and committed human resource capacity. The human resource barriers are referred to as HR barrier. The human resource barriers are intrinsic to the firm. It refers to the insufficient organizational resources for the export market (Al-Hyari, Al-Weshah, \& Alnsour, 2012; Haluk Köksal \& Kettaneh, 2011). The success of every firm depends on the quality of its human resources.

Lack of trained and experienced human resources can cause difficulties in export marketing of the company. Ibeh argued that lack of qualified personnel is a major barrier to the internationalization (Ibeh, 2004). As reported in several articles, lack of management competency is a major barrier to export-marketing activities. Collectively, management attitudes, trained human resources, and commitment towards exports are important factors which enhance the export performance (Hultman, Katsikeas, \& Robson, 2011; Tesfom \& Lutz, 2006; Wagner, 2013).

Deficiency of foreign trade staff is a human resource capacity problem. Human resources were noted as a significant factor in the exporting activity of the firms studied. The feature of the firms studied was related to small and medium scale companies. These firms suffered from disorganization within their frameworks. A Few employed personnel were able to perform multiple tasks. Personnel were involved in other functions and were not fully concentrating on the export activity. In most of the firms studied the chief executives were the main thrust around whom all the exporting activities were performed (Jarreau \& Poncet, 2012). As noted by Ibeh, deficiency of foreign trade staff for the exporting activity is a major barrier to the export activity (Ibeh, 2004).

In addition to deficiency of foreign trade staff suffers, the small size of most of these exporting firms also means that they cannot adequately employ staff for all the specialized departments and need to improvise by doubling most of the functions (Portugal-Perez \& Wilson, 2012). Thus Deficiency of foreign trade staff is highlighted in the explanation of internal barriers. As noted, "Well-trained human resource, management attitude and commitment towards exports are amongst the features that improve the export performance" (Tesfom \& Lutz, 
2006). The studies show most of the firms suffer from the shortage of qualified personnel or organizations needed to perform certain tasks. Most of the employed staff did not have the requisite professional training to deal with the rigors of the export market. They had very limited knowledge about the entire export activity and lacked the required managerial expertise. Firms with high percentage of deficiency in this section reported on average a relatively high degree of importance to all other export barriers as well. Thus, the difficulty in hiring personnel is in complete accordance with the internal barriers.

\subsubsection{Financial Barrier}

The second factor explaining $14.9 \%$ (Cronbach's $\alpha=0.767$ ) of the total variation consists of variables such as "Delay in receiving foreign payments" (0.868), "Deficiency of fiscal support" (0.856), and "Deficiency of government familiarity with foreign trade support plans" (0.607). As noted in the review literature, these variables impose financial resource constraint and adequately fall under company barriers, a type of internal barrier. Components under this factor are therefore clustered together as a single dimension namely export finance barriers and financial barriers. Out of the 71 studied firms, 37 (52.1\%) declared that financial support was of very high importance, $35(49.3 \%)$ firms also claimed that the Delay in receiving foreign payments constitutes a high importance factor. Subsequently, 41 (57.7\%) firms announced that the Deficiency of government familiarity with foreign trade support plans constitutes a highly important factor. The firms studied had various problems in terms of finance. This consisted of the entire financial structure within which their operations are conducted. Mobilizing enough financial capital from the formal financial institutions for their activities was difficult due to the nature and mode of operation. To add to this is the fact that they have very limited knowledge of the government's export programs which are meant to promote SMEs operating in the export sectors. From this analysis, therefore we can conclude that to measure internal export barriers with reference to financial barriers the extracted components are sufficient.

\subsubsection{Market Barriers}

The third dimension which explains an additional 10.9\% (Cronbach's $\alpha=0.408$ ) of the total variations consists of the following variables; "bureaucratic requirements" (0.726), "quality requirements of the foreign countries" $(0.661)$ and "non-tariff barriers in export market" $(0.605)$. These variables have similar characteristics as they tend to be related to the firm externally. We termed these variables as export market barriers and market barriers. The firms' market barriers tend to have a widely varying nature. These include distinguished foreign consumer preferences, the imposition of tariff and non-tariff barrier, unfamiliar business protocols and practices, fierce competition and regulatory import controls by foreign governments. These were some of the problems noted by participants during our research.

The related articles revealed that a substantial number of export problems are due to market barriers. Variables such as bureaucratic requirements for exporting activity contributed to constraining factors of perceived export barriers and had a very high positive loading on the export barrier dimension. Firms studied declared that their exporting activities were constrained by the prevailing bureaucratic requirements in the export and import business. One firm claimed that they were unable to meet the demands of their foreign customers as a result of these bureaucratic requirements, which normally involve documentations by various overlapping departments and agencies and were about to lose the business and markets. Firms studied also stated that the meticulous quality requirements of foreign countries' standards-boards are another constraint to the export performance of their activities. This constraint had a high positive loading on the market factor (Morgan, Katsikeas, \& Vorhies, 2012). Participants indicated that most of the problems are in relation with the technicaladaptability-in and deficiency of information about market requirements as a result of poor quality control techniques, packaging and labeling requirements including poor product design (Freixanet, 2012; Ginevičius \& Šimelytė, 2011; Haluk Köksal \& Kettaneh, 2011). Accordingly, Wortzel and Deng said that exporting standardized products seemed to be easier for inexperienced exporters. Mostly they rely on the importers design and promotional skills (Wortzel \& Deng, 1995). Consequently, bureaucratic requirements, quality requirement of foreign firms, and non-tariff barriers can be adequately classified as market barriers.

\section{Conclusion}

First and foremost the results are particularly important to firms operating in the Anzali free trade zone since improvement in the quality of human resources of a firm meant improved export performance. With a highly significant relationship between human resource barrier and export performance, we recommend that firms in this sector improve the quality of their human resources until they maximize massive benefits that ensue.

Secondly, the findings imply that in developing markets, firms lack the essential managerial obligations to export and in addition they lack required procedural adaptations to meet the demands of the foreign market. Export 
firms usually have to manage an extensive number of activities in their operations on the international market. As the onus is on export managers to enhance their export performance objectives, the implications suggest that they need to develop significant managerial abilities if they want to pass and to adapt to the best possible strategy.

Further, apart from the factors analyzed, other elements may be involved in the relationship between observed export obstructions and export performance. These include accessibility of infrastructure, socio-economic and political environment and risk factors. In order to achieve a more in-depth understanding of the elements that determine the relationship between perceived export barriers and export performance interaction, future studies could incorporate these factors in the analysis. Furthermore, since there are different internationalization problems in several features such as sector, number of employees, turnover, management training, export experience, export expansion, export intensity, contribution of export to profit, mode of entry, level of internationalization and internationalization subsides, these variables should be considered as possible moderators when developing studies in the field of international strategic marketing as they could promote specific studies in analyzing international strategic design and functioning.

\section{References}

Al-Hyari, K., Al-Weshah, G., \& Alnsour, M. (2012). Barriers to internationalisation in SMEs: evidence from Jordan. Marketing Intelligence \& Planning, 30(2), 188-211. http://dx.doi.org/10.1108/02634501211211975

Diamantopoulos, A., \& Kakkos, N. (2007). Managerial assessments of export performance: conceptual framework and empirical illustration. Journal of international marketing, 15(3), 1-31. http://dx.doi.org/10.1509/jimk.15.3.1

Freixanet, J. (2012). Export promotion programs: Their impact on companies' internationalization performance and competitiveness. International Business Review, 21(6), 1065-1086. http://dx.doi.org/10.1016/j.ibusrev. 2011.12.003

Ginevičius, R., \& Šimelytė, A. (2011). Government incentives directed towards foreign direct investment: a case of Central and Eastern Europe. Journal of Business Economics and Management, (3), 435-450. http://dx.doi.org/10.3846/16111699.2011.599415

Hakimian, H. (2011). Iran's Free Trade Zones: Back Doors to the International Economy? Iranian Studies, 44(6), 851-874. http://dx.doi.org/10.1080/00210862.2011.570525

Haluk Köksal, M., \& Kettaneh, T. (2011). Export problems experienced by high-and low-performing manufacturing companies: A comparative study. Asia Pacific Journal of Marketing and Logistics, 23(1), 108-126. http://dx.doi.org/10.1108/13555851111100021

Hultman, M., Katsikeas, C. S., \& Robson, M. J. (2011). Export promotion strategy and performance: the role of international experience. Journal of international marketing, 19(4), 17-39. http://dx.doi.org/10.1509/jim.11. 0022

Ibeh, K. I. N. (2004). Furthering export participation in less performing developing countries: The effects of entrepreneurial orientation and managerial capacity factors. International Journal of Social Economics, 31(1/2), 94-110. http://dx.doi.org/10.1108/03068290410515448

Jarreau, J., \& Poncet, S. (2012). Export sophistication and economic growth: Evidence from China. Journal of development Economics, 97(2), 281-292. http://dx.doi.org/10.1016/j.jdeveco.2011.04.001

Kaiser, H. F., \& Rice, J. (1974). Little Jiffy, Mark IV. Educational and psychological measurement. http://dx.doi.org/10.1177/001316447403400115

Katsikeas, C. S., Leonidou, L. C., \& Morgan, N. A. (2000). Firm-level export performance assessment: review, evaluation, and development. Journal of the Academy of Marketing Science, 28(4), 493-511. http://dx.doi.org/10.1177/0092070300284003

Miandehi, P. M., \& Masrouri, M. Y. (2013). Assessment of Swot Model on Tourism Industry in Sustainable Development of Rural Areas: Case Study on Bandar-E Anzali. World Applied Sciences Journal, 21(3), 455-464. http://dx.doi.org/10.5829/idosi.wasj.2013.21.3.3039

Morgan, N. A., Katsikeas, C. S., \& Vorhies, D. W. (2012). Export marketing strategy implementation, export marketing capabilities, and export venture performance. Journal of the Academy of Marketing Science, 40(2), 271-289. http://dx.doi.org/10.1007/s11747-011-0275-0

Mumford, D. B., Ayub, M., Karim, R., Izhar, N., Asif, A., \& Bavington, J. T. (2005). Development and validation 
of a questionnaire for anxiety and depression in Pakistan. Journal of affective disorders, 88(2), 175-182. http://dx.doi.org/10.1016/j.jad.2005.05.015

Portugal-Perez, A., \& Wilson, J. S. (2012). Export performance and trade facilitation reform: hard and soft infrastructure. World Development, 40(7), 1295-1307. http://dx.doi.org/10.1016/j.worlddev.2011.12.002

Shoham, A., \& Kropp, F. (1998). Explaining international performance: marketing mix, planning, and their interaction. Marketing Intelligence \& Planning, 16(2), 114-123. http://dx.doi.org/10.1108/02634509810 209641

Tesfom, G., \& Lutz, C. (2006). A classification of export marketing problems of small and medium sized manufacturing firms in developing countries. International Journal of Emerging Markets, 1(3), 262-281. http://dx.doi.org/10.1108/17468800610674480

Wagner, J. (2013). Exports, Imports and Firm Survival: First evidence for manufacturing enterprises in Germany. Review of World Economics, 149(1), 113-130. http://dx.doi.org/10.1007/s10290-012-0141-2

Wortzel, L. H., \& Deng, S. (1995). Importer purchase behavior: guidelines for Asian exporters. Journal of Business Research, 32(1), 41-47. http://dx.doi.org/10.1016/0148-2963(94)00008-3

\section{Copyrights}

Copyright for this article is retained by the author(s), with first publication rights granted to the journal.

This is an open-access article distributed under the terms and conditions of the Creative Commons Attribution license (http://creativecommons.org/licenses/by/3.0/). 